\title{
Comparison of Three Methods in Determining the Change in the Treatment of Hypertension in Family Medicine
}

Özgün Araştırma Research Article

Received/Geliş: 15.04.2019 Accepted/Kabul: 14.07.2019 Published Online: 31.08 .2020

Bade Ertürk Arık Erciyes Üniversitesi, Tıp Fakültesi, Aile Hekimliği Ana Bilim Dalı, Kayseri - Türkiye

- badeerturkarik@gmail.com ORCID: 0000-0002-0898-1099

S. Mistık 0000-0003-0657-3881 Erciyes Üniversitesi, Tıp Fakültesi, Aile Hekimliği Ana Bilim Dalı, Kayseri, Türkiye

F. Arık 0000-0001-6929-4666 Tomarza Yaşar Karayel ilç̧e Devlet Hastanesi, Iç Hastalıkları, Kayseri, Türkiye

G. Ertürk Zararsiz 0000-0002-5495-7540 Erciyes Üniversitesi, Tıp Fakültesi, Biyoistatistik, Kayseri, Türkiye

D. Ünalan 0000-0001-9854-437X Erciyes Üniversitesi, Tıp Fakültesi, Halil Bayraktar Sağlık Meslek Yüksek Okulu, Kayseri, Türkiye

A. Oğuzhan 0000-0001-9295-6410 Erciyes Üniversitesi, Tıp Fakültesi, Kardiyoloji Anabilim Dalı, Kayseri, Türkiye

B. Tokgöz 0000-0003-0880-3396 Erciyes Üniversitesi Tıp Fakültesi, Nefroloji Anabilim Dalı, Kayseri, Türkiye

Cite as: Ertürk Arık B, Mıstık S, Arık F, Ertürk Zararsız G, Ünalan D, Oğuzhan A, Tokgöz B. Comparison of three methods in determining the change in the treatment of hypertension in family medicine. Tepecik Eğit. ve Araşt. Hast. Dergisi. 2020;30(2):182-9.

\section{Aile Hekimliğinde Hipertansiyon Tedavisinde Değişiklik Kararı Vermede Üç Yöntemin Karşılaştırılması}

\author{
Bade Ertürk Arık $\oplus^{\oplus}$, Selçuk Mıstık $\oplus^{\oplus}$, Ferhat Arık $\oplus^{\oplus}$, Gözde Ertürk Zararsız $\oplus^{\oplus}$, \\ Demet Ünalan $\odot$, Abdurrahman Oğuzhan $\odot$, Bülent Tokgöz $\odot$
}

\section{ABSTRACT}

Objective: This study aims to compare 24 hour-Ambulatory Blood Pressure Monitorization and Home Blood Pressure Monitorization (HBPM) and Office Blood Pressure Monitorization (OBPM) of hypertension patients whose $B P$ was thought to be not under control despite appropriate medication and to decide the method that could be used in family medicine practice.

Method: Fifty patients whose BP values measured in office setting whose blood pressures were not under control despite antihypertensive treatment Each patient was assessed with at least $3 O B P M s, 7$ day-monitorization of $B P$ measurements at home (HBPM) and ambulatory blood pressure monitorization (ABPM) for 24 hours.

Results: A moderately positive correlation was detected between ABPM, OBPM and weekly HBPM.

Conclusion: The results of this study have shown that ABPM which is a gold standard is in good agreement with $B P M H$, but weakly compatible with OBPM Therefore, in hypertension patients with higher BP measurements detected in office, priorly ambulatory blood pressure measurements should be performed, if not possible, blood pressures should be monitored for at least 3-4 days at home.

Keywords: Hypertension, ambulatory blood pressure, office blood pressure, home blood pressure

\section{öz}

Amaç: Bu çalışmanın amacı, tansiyon ilacı kullanmasına rağmen ofis ölçümlerine göre kan basınçları kontrol altında olmadığı düşünülen hipertansiyon hastalarında, 24 saatlik ambulatuar kan basıncı monitorizasyonu ile ofis ve evde tansiyon ölçümlerini karşılaştırmak ve aile hekimliğinde kullanılabilecek yönteme karar vermektir

Yöntem: Çalışmaya antihipertansif tedavi almakta olan ve ofis ölçümlerinde kan basınçları kontrol altında olmayan 50 hasta alındı. Tüm hastalara üç ofis kan basıncı ölçümü, yedi günlük evde kan basıncı takibi ve 24 saatlik ambulatuar kan basıncı monitorizasyonu ölçümü uygulandı.

Bulgular: Ambulatuar kan basıncı monitorizasyonu ile ofis kan basıncı ölçümü ve evde haftalık kan basıncı takipleri arasında genel olarak pozitif yönde ve orta kuvvette bir ilişki saptandı.

Sonuç: Bu çalıșmanın sonuçları, altın standart olan ambulatuar kan basıncı ölçümü ile evde yapılan kan basıncı ölçümünün uyumlu olduğu, ofis ölçümlerinin ise zayıf uyumlu olduğunu gösterdi. Bu sebeple ofis kan basıncı ölcümleri yüksek tespit edilen hipertansiyon hastalarında, öncelikli olarak ambulatuar kan basıncı ile ölçüm yapılmalı, ambulatuar kan basıncı takibi yapılamıyor ise evde en az 3-4 günlük kan basıncı takibi yapılmalıdır.

Anahtar kelimeler: Hipertansiyon, ambulatuar kan basıncı, ofis kan basıncı, evde kan basıncı

(C) Telif hakkı TC. Sağlık Bakanlğı izmir Tepecik Eğit. ve Arast. Hastanesi. Logos Tip Yayıncluk tarafindan yayınlanmaktadır.

Bu dergide yayınlanan bütün makaleler Creative Commons Attf-GayriTicari 4.0 Uluslararası Lisansı ile lisanslanmıştr.

(c) Copyright Association of Publication of the T.C. Ministry of Health İmir Tepecik Education and Research Hospital.

This journal published by Logos Medical Publishing.

Licenced by Creative Commons Attribution-NonCommercial 4.0 International (CC BY) 


\section{INTRODUCTION}

Hypertension ( $\mathrm{HT}$ ) is a very important disease with increasing frequency both in the world and in our country and threatens public health due to its complications. HT accounts for $13 \%$ of deaths worldwide, and it is estimated that around one billion people worldwide are affected by $\mathrm{HT}^{(1)}$.

According to World Health Organization (WHO) data, the prevalence of HT is very high and it is the first cause of preventable deaths in the world (2). The control rate of HT was found to be $28.7 \%$ in hypertensive individuals and $53.9 \%$ in patients under treatment ${ }^{(3)}$.

In addition to the low awareness of the disease, inadequate and ineffective treatment of the disease plays a role in the inability to effectively control BP in patients .

The first step in the treatment of HT is the correct diagnosis. This is achieved by providing the necessary equipment and environmental conditions for detecting BP and making measurements using the right technique.

False positive or false negative results may be obtained due to various errors in BP measurements. As a result of incorrect measurements, diagnosis and treatment are delayed in some hypertensive individuals, while some individuals undergo unnecessarily lifelong treatment even though they are not really ill. Finally, erroneous measurement causes serious increase in financial burden ${ }^{(4)}$.

Today, although ambulatory blood pressure measurement (ABPM) is the gold standard for the detection of hypertension, hypertension is also diagnosed, and followed up with home blood pressure measurements (HBPMs) and office blood pressure measurements (OBPMs)
In our study we aimed to detect, whether there is a difference between ambulatory, home, and office blood pressure measurements in patients followed up with the diagnosis of HT, which is an important public health problem in our country and in the world, and determine the methods that should be preferred in the first step when deciding a change in the treatment.

\section{BATERIALS and METHODS}

This study was conducted in Erciyes University Department of Family Medicine policlinics between 01 February 2017 and 1 August 2017 with patients diagnosed with primary HT who were using one or more than five main classes (diuretic, calcium channel blocker, ACE inhibitor, angiotensin receptor blocker) of hypertension treatment within the last three months and had blood pressure values greater than systolic $\geq 140 \mathrm{mmHg}$, diastolic $\geq 90 \mathrm{mmHg}$ in the office measurements despite antihypertensive treatment and agreed to participate were included in the study. Patients who were older than 18 years of age and who could wear a holter device were included in the study regardless of gender.

Arterial BP measurements of the patients in the office were carried out in an environment free of noise and temperature in accordance with the correct measurement rules. Patients were informed about avoiding exercise and not eating and drinking caffeinated drinks such as coffee, tea, cola, and smoking cigarettes half an hour before BP measurement and if needed they were waited 30 minutes for measurement.

During the measurement, the blood pressure was measured by paying attention that the patient's relaxed arm at the level of the heart was not squeezed, while he/she was sitting silently for at least 5 minutes on his back resting on the back of the chair without crossing legs. Tel-O-Graph ${ }^{\circledR}$ BT brand (manufacturer; IEMIndustrielle Entwicklung Medizintechnik 
und Vertriebsgesellschaft mbH Cockerillstrabe 69, 52222, Stolberg, Germany, 2015) with high measurement quality (approved according to BHS (A/A classification) and ESH), easy to use for each patient for measurement and use in the clinic done with sphingomanometer. Simultaneous BP measurements were performed on both arms in the office measurements. Three consecutive measurements were taken from the arm with a high BP at 1-2 minute intervals. The average of the three measurements was calculated and recorded in the patient's file.

The measuring devices given to patients for home measurements were the same as those for office measurements. Patients were told how to measure $B P$. The patients were instructed to take measurements twice a day, 12 hours apart, in the morning and evening for 7 days.

Twenty-four-hour blood pressure monitoring was performed with Mobil-O-Graph NG (I.E.M. Stolberg Germany) using ambulatory blood pressure devices. An appropriate size cuff was used for each patient. The device was programmed to perform BP measurements at 15 minute intervals when patients are awake and 30 minutes when they are asleep. In order for the measurements to be meaningful, it was ensured that the device made at least $70 \%$ accurate measurements. Five patients were excluded from the study because more than $70 \%$ measurements were erroneous.

In the evaluation of the data; Data obtained from 50 participants were transferred to SPSS for Windows 22 (Statistical Package for Social Sciences) packet programe.

We used Bland-Altman graphics also known as the study of method comparison and passing-bablok regression analyses. Data distribution were checked with histogram, q-q graphics and Shapiro-Wilk test. In comparison of groups and for repetitive measurements we used 2-sample dependent t-test and vari- ance analysis, respectively. Multiple comparisons are made with Bonferroni method. Comparison between methods of measurement was made with PassingBablok regression analyses and we created BlandAltman graphics. In case of model constant obtained with Passing-Bablok regression analyses not containing " 0 " and of regression coefficient not containing "1"; respectively a sytematic and propartional error was determined. At the same time for assesing agreement between methods, we calculated Kappa coefficient with also intraclass and concordance correlation coefficients. Agreement between methods was accepted at a high level if coefficients are higher than $\% 81$, as medium if between $\% 41$ and $\% 61$, as weak agreement if between \%21 and \%40 and as very weak if lower than \%20. Data were analyzed with R 3.2.0 (www.r-project.org). Values of $p<0.05$ were considered significant

\section{RESULTS}

The study was conducted between February 2017July 2017 with 50 patients over 18 years of age. Twenty-nine (58\%) participants were female and 21 $(42 \%)$ were male. The mean age of all patients was $57 \pm 10.54$ years (minimum, 31 and maximum, 76 years).

The study participants consisted of faculty members $(n=2 ; 4 \%)$, housewives ( $n=28 ; 56 \%)$, civil servants $(n=4 ; 8 \%)$ other professionals $(n=16 ; 32 \%)$, married $(n=46 ; 92 \%)$ and single $(n=4 ; 8 \%)$.

Only 5 participants were cigarette smokers and the rest were nonsmokers. 16 participants had a comorbid disease other than $\mathrm{EH}$ and 32 paticipants had not any comorbid chronic disease.

BMI of one (\%2) participant was $25,53 \mathrm{~kg} / \mathrm{m}^{2}$. Body mass indexes were between $25-30 \mathrm{~kg} / \mathrm{m}^{2}$ in 25 (50\%), and between $30-40 \mathrm{~kg} / \mathrm{m}^{2}$ in $23(46 \%)$ and BMI was $41 \mathrm{~kg} / \mathrm{m}^{2}$ in 1 (2\%) iparticipant. 
Mean SBP and DBP values were found respectively; in ABPM 129.92 $\pm 14.87 \mathrm{a} \mathrm{mmHg}$ and $80.40 \pm 11.01 \mathrm{a}$ $\mathrm{mmHg}$, in HBPM $137.42 \pm 14.02 \mathrm{~b} \mathrm{mmHg}$ and $96.38 \pm 13.11 \mathrm{~b} \mathrm{mmHg}$, in OBPM $158.21 \pm 17.81 \mathrm{c} \mathrm{mmHg}$ and $83.28 \pm 9.40 \mathrm{c} \mathrm{mmHg}$. Mean SBP and DBP values between three methods were significantly different. Mean SBP values measured at day time were $131.82 \pm 14.86 \mathrm{mmHg}$ in ABPM and $137.85 \pm 14.69$ $\mathrm{mmHg}$ in HBPM; and the diffrence between two mean values were significant. Mean DBP values measured at day time were found $81.92 \pm 11.20$ $\mathrm{mmHg}$ in ABPM and 83.59 $\pm 9.91 \mathrm{mmHg}$ in HBPM; and the diffrence between two mean values were insignificant. Mean SBP values measured at night were $122.10 \pm 16.45 \mathrm{mmHg}$ in ABPM and 137.28 \pm 14.37 $\mathrm{mmHg}$ in HBPM; and the diffrence between two mean values were significant. Mean DBP values measured at night were $74.46 \pm 11.02 \mathrm{mmHg}$ in ABPM and $82.97 \pm 9.90 \mathrm{mmHg}$ in HBPM; and the diffrence between two mean values were significant Table 1.

Table 1. Comparison of the mean of systolic and diastolic blood pressure measurements between ambulatory, home and office methods.

\begin{tabular}{ccccc}
\hline Variable & $\begin{array}{c}\text { Ambulatory } \\
(\mathbf{n}=50)\end{array}$ & $\begin{array}{c}\text { Home } \\
(\mathbf{n}=50)\end{array}$ & $\begin{array}{c}\text { Office } \\
(\mathbf{n}=50)\end{array}$ & $p$ \\
\hline Total & & & & \\
SBP & $129.92 \pm 14.87^{\mathrm{a}}$ & $137.42 \pm 14.02^{\mathrm{b}}$ & $158.21 \pm 17.81^{\mathrm{c}}$ & $<0.001$ \\
DBP & $80.40 \pm 11.01^{\mathrm{a}}$ & $96.38 \pm 13.11^{\mathrm{b}}$ & $83.28 \pm 9.40^{\mathrm{c}}$ & $<0.001$ \\
Day & & & & \\
SBP & $131.82 \pm 14.86$ & $137.85 \pm 14.69$ & - & $<0.001$ \\
DBP & $81.92 \pm 11.20$ & $83.59 \pm 9.91$ & - & 0.115 \\
Night & & & & $<0.001$ \\
SBP & $122.10 \pm 16.45$ & $137.28 \pm 14.37$ & - & $<0.001$ \\
DBP & $74.46 \pm 11.02$ & $82.97 \pm 9.90$ & - & \\
\hline
\end{tabular}

SBP: Systolic Blood Plessure, DBP: Diastolic Blood Plessure. Data were expressed as mean \pm standard deviation. The different letters on the same line represent the mean difference between the methods.
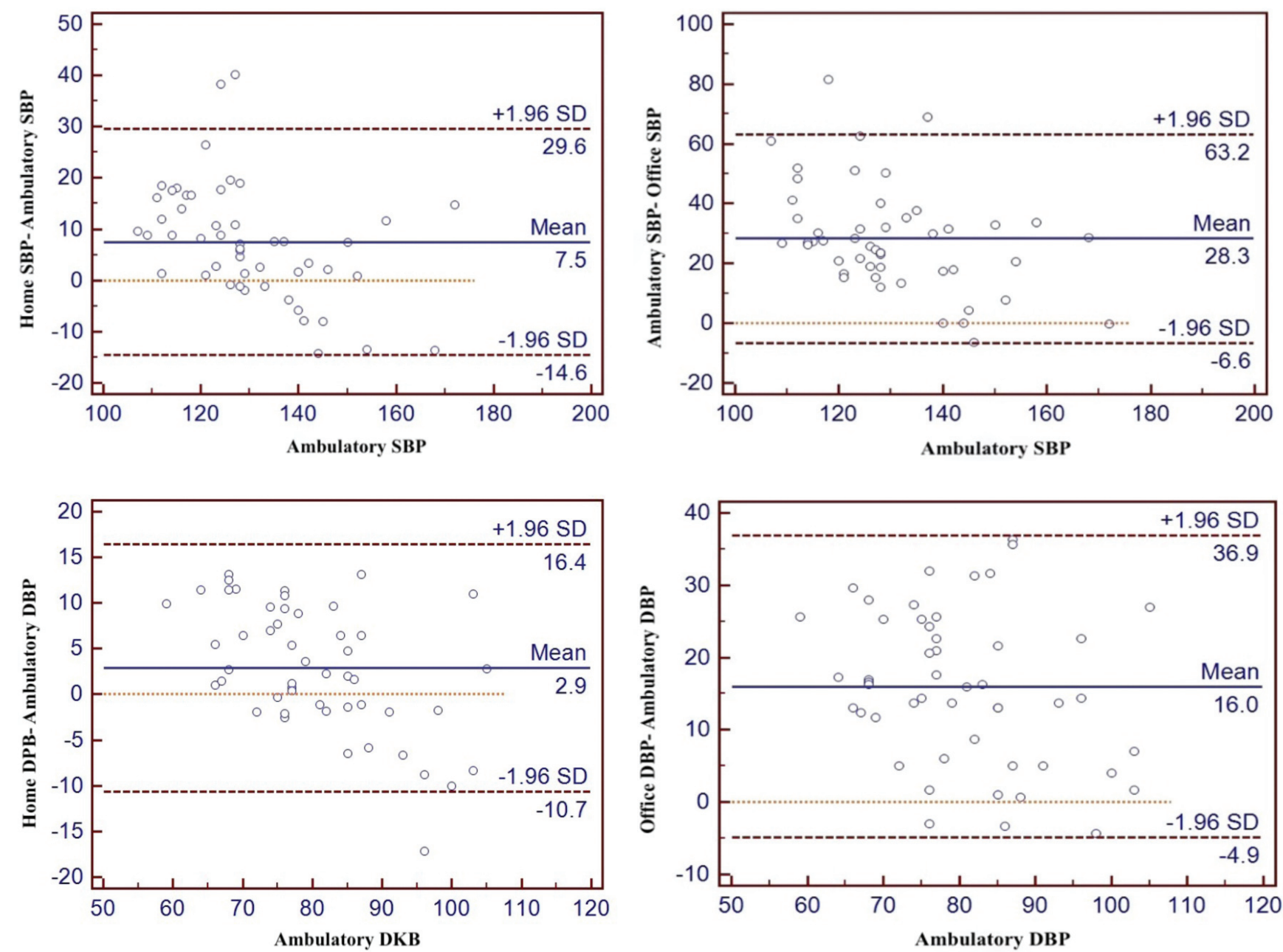

Figure 1. Bland-Altman graphics, comparison and assessement of agreement between ABPM, BPMH and BPMO methods in regard of SBP and DBP. 
Table 2. Comparison of systolic and diastolic blood pressure measurements with ambulatory method at home and office measurement methods and compliance analysis.

\begin{tabular}{|c|c|c|c|c|c|c|c|c|c|c|}
\hline \multirow[b]{3}{*}{ Group } & \multicolumn{5}{|c|}{ Home - Ambulatory } & \multicolumn{5}{|c|}{ Office-Ambulatory } \\
\hline & \multicolumn{2}{|c|}{$\begin{array}{l}\text { Passing-Bablok } \\
\text { Regression }\end{array}$} & \multicolumn{3}{|c|}{$\begin{array}{l}\text { Aggreement } \\
\text { Statistics }\end{array}$} & \multicolumn{2}{|c|}{$\begin{array}{c}\text { Passing-Bablok } \\
\text { Regression }\end{array}$} & \multicolumn{3}{|c|}{$\begin{array}{l}\text { Agreement } \\
\text { Statistics }\end{array}$} \\
\hline & Constant & $\begin{array}{l}\text { Regression } \\
\text { Coefficient }\end{array}$ & icc & $\mathrm{CCC}$ & K & Constant & $\begin{array}{l}\text { Regression } \\
\text { coefficient }\end{array}$ & icc & $\mathrm{CCC}$ & $\mathrm{K}$ \\
\hline \multicolumn{11}{|l|}{ SBP Total } \\
\hline $\begin{array}{l}\text { Coefficient } \\
\% 95 \mathrm{Ci} \\
\text { Interpretation }\end{array}$ & $\begin{array}{c}29.14 \\
(-2.14 / 56.72) \\
\text { No } \\
\text { Constant } \\
\text { Error }\end{array}$ & $\begin{array}{c}0.82 \\
(0.61 / 1.07) \\
\text { No } \\
\text { Proportional } \\
\text { Error }\end{array}$ & $\begin{array}{c}0.76 \\
(0.42 / 0.89) \\
\text { Good } \\
\text { Agreement }\end{array}$ & $\begin{array}{c}0.61 \\
(0.43 / 0.74) \\
\text { Moderate } \\
\text { Agreement }\end{array}$ & $\begin{array}{c}0.43 \\
(0.17 / 0.70) \\
\text { Moderate } \\
\text { Agreement }\end{array}$ & $\begin{array}{c}-1.06 \\
(-77.93 / 44.52) \\
\text { No } \\
\text { Constant } \\
\text { Error }\end{array}$ & $\begin{array}{c}1.22 \\
(0.85 / 1.81) \\
\text { No } \\
\text { Proportional } \\
\text { Error }\end{array}$ & $\begin{array}{c}0.28 \\
(-0.19 / 0.61) \\
\text { Weak } \\
\text { Agreement }\end{array}$ & $\begin{array}{c}0.16 \\
(0.05 / 0.27) \\
\text { Weak } \\
\text { Agreement }\end{array}$ & $\begin{array}{c}0.01 \\
(-0.09 / 0.10) \\
\text { Very Weak } \\
\text { Agreement }\end{array}$ \\
\hline \multicolumn{11}{|l|}{ DBP Total } \\
\hline $\begin{array}{l}\text { Coefficient } \\
\% 95 \mathrm{Ci} \\
\text { Interpretation }\end{array}$ & $\begin{array}{c}18.87 \\
(1.77 / 31.95) \\
\text { Constant } \\
\text { Error } \\
\text { is Present }\end{array}$ & $\begin{array}{c}0.80 \\
(0.64 / 1.01) \\
\text { No } \\
\text { Proportional } \\
\text { Error }\end{array}$ & $\begin{array}{c}0.85 \\
(0.72 / 0.92) \\
\text { Very Good } \\
\text { Agreement }\end{array}$ & $\begin{array}{c}0.74 \\
(0.60 / 0.84) \\
\text { Good } \\
\text { Agreement }\end{array}$ & $\begin{array}{c}0.46 \\
(0.14 / 0.78) \\
\text { Moderate } \\
\text { Agreement }\end{array}$ & $\begin{array}{c}-3.88 \\
(-43.12 / 22.33) \\
\text { No Constant } \\
\text { Error }\end{array}$ & $\begin{array}{c}1.25 \\
(0.92 / 1.77) \\
\text { No } \\
\text { Proportional } \\
\text { Error }\end{array}$ & $\begin{array}{c}0.49 \\
(-023 / 0.79) \\
\text { Moderate } \\
\text { Agreement }\end{array}$ & $\begin{array}{c}0.32 \\
(0.18 / 0.45) \\
\text { Weak } \\
\text { Agrement }\end{array}$ & $\begin{array}{c}0.21 \\
(0.06 / 0.34) \\
\text { Weak } \\
\text { Agreement }\end{array}$ \\
\hline
\end{tabular}

SBP: Systolic blood pressure, DBP: Diastolic blood pressure, ICC: Intra-class correlation coefficient, CCC: concordance correlation coefficient, $\mathrm{K}$ : Kappa coefficient, CI: Confidence interval. Confidence intervals were expressed as $95 \%$ confidence level (lower limit / upper limit). Comments Passing-Bablok regression analysis for the presence of systematic or proportional error, the compliance of the strength of compliance statistics (0-0.20: very weak, 0.21-0.40: weak, 0.41-0.60: moderate, 0.61-0.80: good, 0.81-1.00: very good).

Bland-Altman graphics and Passing-Bablok regression analyses we used in comparison and assessement of agreement between ABPM, HBPM and OBPM methods in regard of SBP and DBP (Figure 1). Agreement analyses are shown in Table 2.

There was an equilibrium between home systolic blood pressure (HSBP) and ambulatory systolic blood pressure (ASBP) in the form of HSBP $=29.14+0.82 \mathrm{X}$ ASBP.

An equalization between home diastolic blood pressure (HDBP) measurement and ambulatory diastolic blood pressure (ADBP) measurement was obtained as $\mathrm{HDBP}=18.87+0.80 \times \mathrm{ADBP}$.

There was an equation between office systolic blood pressure (OSBP) and ambulatory systolic blood pressure $(\mathrm{ASBP})$ as $\mathrm{ASD}=1.06+1.22 \mathrm{X}$ ASDB.

There was an equation between office diastolic blood pressure (ODBP) and ambulatory diastolic blood pressure (ADBD) as ODDB $=-3,88+1,25 \times$ ADBD.

In 41 patients including 19 patients whose ABPM results were $<120 / 80 \mathrm{mmHg}$ and 22 patients having SBP between 120-138 mmHg and DBP between 80-89 mmHg; we recommended them to revisit the outpatient clinic after 3 months with advices on restriction of salt intake and on regulations of life style and dietary habits such as starting to a diet without changing medication.

In 5 of 9 patients having SBP between 140-175 $\mathrm{mmHg}$ and DBP between 90-99 $\mathrm{mmHg}$ in ABPM, doses of current medication increased with restriction of salt intake and regulations of life style wheras in 4 of the same 9 patients a second antihypertensive medication were added.

\section{DISCUSSION}

In terms of both economical anf practical advantage the most preferred diagnostic method for hypertension is OBPM .

Higher blood pressure values due to white coat effect may be found in OCD measurements and masked, episodic or nocturnal hypertension patients can be omitted. Ambulatory blood pressure measure- 
ment is recommended as the most reliable method for diagnosing hypertension and monitoring treatment ${ }^{(6)}$. Monitoring BP at home throughout the day and night is not as useful as ABPM, but the diagnosis of masked hypertension and isolated office hypertension can be also accurately detected with BP measurements at home.

Correct and reliable measurement of increase in BP is crucially related to the method of measurement used.

First of all, we compared these three methods to assess their agreement for determining blood pressure most correctly. When papers comparing ABPM with HBPM and OBPM are reviewed, they were related only to studies which involve also EH patients without medication.

Analyses show that 1) Mean SBP values measured with HBPM and ABPM have a good agreement and mean DBP values measured with HBPM and ABPM have a very good agreement, 2) Mean SBP values measured with OBPM and ABPM have a weak agreement and mean DBP balues measured with OBPM and with $A B P M$ have a weak agreement.

Mean BP values measured with HBPM have been seen in a higher agreement with mean $B P$ values measured with ABPM compared to mean BP values measured with OBPM. In previous studies BP values measured with HBPM have been found to be lower than BP values measured with OBPM ${ }^{(6,7)}$. In addition, the HBPM is both inexpensive and reliable in detecting daily BP changes, and according to results of our study, the HBPM was reported to be closer to the ABPM results than the OBPM ${ }^{(8,9)}$. No statistical difference was found between the methods.

However, the difference between methods is clinically negligible.

This difference is much less in the HBPM values and is closer to the ABPM results.
HBPM values better than OBPM values may give us an idea, in order to decide our course of treatment with higher values. However, the most accurate results can be obtained by ambulatory measurement in patients with high limit values of $135-85 \mathrm{mmHg}$. The 2013 ESH/ESC guideline also recommends the use of ABPM method for individuals with OBPM results at borderline ${ }^{(10)}$. The higher the number of measurements, the greater the accuracy of the average value.

In the study data found in the literature and blood pressure guidelines, it has been stated that the all three methods namely ABPM, HBPM and OBPM can be used in the diagnosis and monitorization of blood pressure, and the methods have several advantages over each other ${ }^{(11)}$.

In our study 34 (\%68) persons had higher values with OBPM. Since most of the studies in literature are population surveys or focus to stage 1 hypertensive individuals, there are no sufficient evidence in literature on the higher values detected with OBPMs of untreated patients. Since our patients had known primary hypertension, it was seen that occasional differences in nutritional habits (such as increased salt consumption), factors effective on personal activity such as excitement, sadness and stress are the reasons of increased incidence of patients with irregular uncontrolled hypertension.

Patients with hypertension were found to be more sensitive to lifestyle variabilities and fluctuations in blood pressure values which were seen within a short time. In our study, high blood pressure values may be found more frequently because the participants were not receiving adequate treatment and their blood pressures were not at the targeted levels.

Since our patients were primary HT patients, we had to arrange our treatment by making separate evaluations for each individual according to their personal characteristics. 
If the mean BP measurements are above 125/76 $\mathrm{mmHg}$ and below 135/85 $\mathrm{mmHg}$, the ABPM can be used for diagnosis. In addition to these, for the diagnosis of $\mathrm{HT}$ and the effectiveness of antihypertensive treatments, HBPM should be started at least 3, but mostly recommended 7 days before the doctor visits. The patient should not take any antihypertensive, and measurements should be within 1 hour after waking up in the morning and in the evening, and the first day measurements should be excluded from the assessment due to probable inaccuracy of BP measurements or anxiety of the patients.

\section{CONCLUSIONS}

A positive and moderately strong relationship was found between the ABPM and the HBPM and OBPM.

As a result of the statistical analysis of our study, both HBPM and OBPM can be used to define high blood pressure in primary care. However, differences between methods were clinically significant (8-30 units for systolic, 3-15 units for diastolic BP measurements). At high BP measurements, all three methods can be used reliably to diagnose hypertension. However, at borderline high BP values, if the mean blood pressure measurements are $>125 / 76<135 / 85$ $\mathrm{mmHg}, \mathrm{ABPM}$ should be used for diagnosis.

HBPM is more in agreement with ABPM. For this reason HBPM has priority in diagnosis and treatment follow-up in terms of blood pressure measurements compared to OBPM.

With patients unable to undergo HBPM (unable to measure BP properly, unable to cooperate, and unable to afford device), OBPM may be used to diagnose $\mathrm{EH}$. Yet in these cases white coat hypertension should be taken into consideration.

Since with HBPM we are able to measure BP more frequently and especially obtain morning/evening measurements which are especially important for hypertension-related morbidity and mortality; it might be possible to replace ABPM with the combination of OBPM and HBPM. ABPM might be used selectively if required.

There is a significant difference between the ABPM and HBPM/OBPM methods. ABPM is a safe method that can be easily applied by all physicians in family medicine outpatient clinics. In family medicine outpatient clinics, decision-making for hypertension treatment should be done firstly acoording to ABPM results. Especially in patients with high risk of developing target organ damage, ABPM should be preferred first.

Ethics Committee Approval: Erciyes University Clinical Research Ethics Committee approval was obtained (Project Code: TTU-2016-6687).

Conflict of Interest: None.

Funding: We would like to thank Erciyes University Scientific Research Projects (BAP) unit for their contribution.

Informed Consent: Receipt.

\section{REFERENCES}

1. World Health Organization. A global brief on Hyper tension World Health Day 2013. World Heal Organ. 2013;1-40.

2. MM MCS. Global health risks: mortality and burden of disease attributable to selected major risks. World Heal Organ Geneva, Switz. 2009.

3. Altun B, Arici M, Nergizoğlu G, Derici U, Karatan O, Turgan C, et al. Prevalence, awareness, treatment and control of hypertension in Turkey (the PatenT study) in 2003. J Hypertens. 2005;23(10):1817-23. [CrossRef]

4. Alpert BS, Quinn D, Gallick D. Oscillometric blood pressure: A review for clinicians. Vol. 8, Journal of the American Society of Hypertension. 2014. p. 930-8. [CrossRef]

5. Mayor S. Hypertension diagnosis should be based on ambulatory blood pressure monitoring, NiCE recommends. BMJ. 2011;343:d5421. [CrossRef]

6. Parati G, Omboni S. Role of home blood pressure telemonitoring in hypertension management: An update. Blood Press Monit. 2010;15(6):285-95. [CrossRef]

7. Mallick S, Kanthety R, Rahman M. Home blood pressure monitoring in clinical practice: a review. Am J Med. 2009;122(9):803-10. [CrossRef]

8. Kikuya M, Ohkubo T, Metoki H, Asayama K, Hara A, Obara T, et al. Day-by-day variability of blood pressure and heart rate at home as a novel predictor of prognosis: The Ohasama 
study. Hypertension. 2008;52(6):1045-50. [CrossRef]

9. Hodgkinson J, Mant J, Martin U, Guo B, Hobbs FDR, Deeks JJ, et al. Relative effectiveness of clinic and home blood pressure monitoring compared with ambulatory blood pressure monitoring in diagnosis of hypertension: Systematic review. BMJ. 2011;343(7814).

10. Members AF, Mancia G, Fagard R, Narkiewicz K, Redon J, Zanchetti A, et al. 2013 ESH/ESC Guidelines for the management of arterial hypertensionThe Task Force for the manage- ment of arterial hypertension of the European Society of Hypertension (ESH) and of the European Society of Cardiology (ESC). Eur Heart J. 2013;34(28):2159-19. [CrossRef]

11. O’Brien E, Atkins N, Stergiou G, Karpettas N, Parati G, Asmar $\mathrm{R}$, et al. European Society of Hypertension International Protocol revision 2010 for the validation of blood pressure measuring devices in adults. Vol. 15, Blood Pressure Monitoring. 2010. p.23-38. [CrossRef] 